
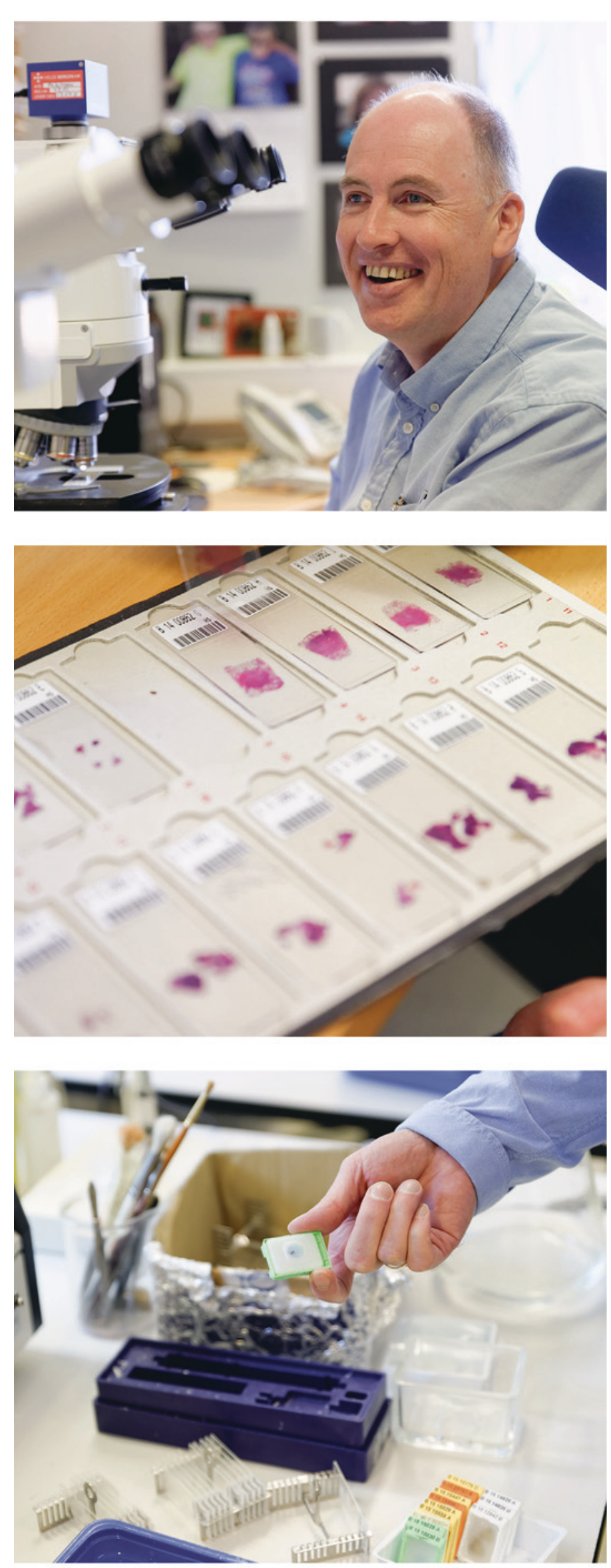

Foto: Magne Sandnes

\section{Klassisk fag i rask endring}

\author{
Lars Helgeland er overlege i patologi ved Avdeling for \\ patologi, Haukeland universitetssykehus. Han mener \\ at patologifaget er inne i sin mest spennende tid hittil \\ i historien.
}

\section{Skjer det noe interessant innen patologien for tiden?} Grunnmetoden i diagnostisk patologi er fortsatt, som det har vært siden 1800-tallet, mikroskopisk unders $ø$ kelse av vevssnitt og cytologiske utstryk. Men to viktige metoder har tilkommet de siste 10-20 årene: Immunhistokjemi, der immunologiske teknikker brukes til å undersøke proteinuttrykk i celler og vev, og molekylærpatologi, der genetiske forandringer i celler undersøkes med molekylærbiologiske teknikker. Disse metodene er blitt uvurderlige verktøy spesielt i kreftdiagnostikk, og det er patologen som integrerer resultatene til en endelig diagnose. Svulstene kan klassifiseres presist, og metodene gir viktig prognostisk informasjon, men også prediktiv informasjon med hensyn til valg av behandling. Molekylære analyser brukes til å analysere genforandringer i kreftsvulster. Genforandringene kan predikere respons på medikamenter som er rettet mot molekyler som styrer celledeling og vekst, f.eks. analyse av epidermal vekstfaktorreseptor (EGFR) ved ikke-småcellet lungekreft og metastatisk coloncancer.

Ny avansert teknologi som hittil har vært mest benyttet i forskningen, slik som dypsekvensering og proteomikk, har begynt å få anvendelse i patologidiagnostikken og vil bli et viktig element i persontilpasset medisin. Det vil bli utfordrende for faget i fremtiden å ivareta tradisjonell morfologisk kompetanse og samtidig opparbeide kunnskap om nye metoder og bruk av disse. Vi er relativt få leger som jobber med et stort diagnostisk fagfelt som blir stadig mer krevende, og subspesialisering i forhold til fag- og organområder er nødvendig for å følge med i utviklingen. Det er viktig med synliggjøring av faget, både på medisinstudiet for å sikre god rekruttering, men også overfor beslutningstakere, som ofte ikke har kjennskap til de nødvendige investeringene i utstyr og personell som følger med utviklingen. Utfordringene er store, men faget er også inne i sin mest spennende tid hittil.

\section{Vil du anbefale en ny og spennende artikkel?}

En artikkel fra to patologer fra Harvard Medical School der man diskuterer betydningen av nye tekniske fremskritt i faget (1).

\section{Hva er ditt favoritthjelpemiddel på jobb?}

Patologidiagnostikk skiller seg fra andre laboratoriefag ved at hver individuelle pasientprøve analyseres og tolkes av en patolog. I vanskelige tilfeller er det viktig å kunne diskutere med en kollega og ha rikelig med spesiallitteratur tilgjengelig. Favorittlitteraturen er Verdens helseorganisasjons blåbokserie (WHO bluebooks) om klassifikasjon av svulster i forskjellige organsystemer.

\section{Anbefalt litteratur \\ 1. Wall DP, Tonellato PJ. The future of genomics in pathology. F1000 Med Rep 2012; 4: 14}

Har du tips til personer vi kan intervjue? Ta kontakt med lise.morkved.helsingenalegeforeningen.no 